\title{
Evaluation of Adult Environmental Awareness Behaviours in Terms of Social Learning Theory according to Perceptions of Primary and Secondary School Students
}

\author{
Erol Ata ${ }^{1}$ \\ ${ }^{1}$ Amasya University, Turkey \\ Correspondence: Erol Ata, Amasya Unıversity, Turkey. E-mail: erolata.ea@gmail.com \\ This paper was orally presented at th $4^{\text {th }}$ International Symposium on Environment and Morals Congress held \\ between 27-29 June 2018 in cooperation with Environmental Foundation, ÇEKUD, in Sarajevo.
}

Received: November 1, 2018

Accepted: November 21, 2018

Online Published: December 3, 2018

doi:10.5430/ijhe.v7n6p54

URL: https://doi.org/10.5430/ijhe.v7n6p54

\begin{abstract}
It has been a well-known fact that educational activities are significant in approaches directed to permanent solutions for environmental problems. To grow individuals who have awareness on their surroundings and are conscious about environment can be considered as an effective way of dealing with these problems. It is necessary to inform individuals about environment and to make them have innovative perspectives, by having positive attitudes. That is, individuals must be encouraged to change their attitudes and behaviours in a positive way. It is not possible to realize these aims only by means of instructing them. Becoming role models for the young makes the process easier and provides permanent learnings. Within this context, Social Learning Theory (SLT), posited by Albert Bandura, argues that learning by observations and imitations are important for children to acquire new knowledge, attitudes or behaviours. The purpose of this current study was to evaluate the adult environmental awareness behaviours in terms of SLT according to perceptions of primary and secondary school students. The perceptions of students were examined in terms of some variables such as gender, school grade, school type, parents' educational background. Screening method was employed as a research design in this study. The population of the study was comprised of primary and secondary school students in Amasya city of Turkey. A questionnare developed by the researcher and called as "Observation Questionnaire on Environmental Behaviours Displayed by Adults" was employed in order to determine how they perceive the adults in terms of environment. Analysis of data revealed that students' perceptions towards adults' environmental awareness behaviours showed differences in terms of gender, whereas there weren't any significant differences in terms of school grade, school type and parents' educational background.
\end{abstract}

Keywords: environmental behaviour, environmental education, social learning theory, environment awareness, observation

\section{Introduction}

As it is in the case of Tanner's study (1980), this present study begins with the premise that the ultimate goal of environmental education (EE) is the pursuing of a resource-rich planet for future generations. Learning encompasses acquiring or changing knowledge, skills, stragegy, beliefs, attitudes and behaviors. Human beings learn knowledge, a language, motor and social skills and this can be realized in several forms (Shunk, 2012). In the literature, there has been a consensus that learning is a significant action, but there have been widely different ideas on learning processes, results and objectives. Three core features domain learning: Including change, being a process and going on through experiences. Widespread evidence has shown that there have been a great number of learning theories which attempts to explain how learning takes place. The most striking of these can be listed as: Behavioral Learning Theory (classical conditioning, operant conditioning, etc.); Social Cognitive Theory (being a model, self-efficacy, etc.); Information Processing Theory and Experimental Theory of Learning (Dewey) (Shunk, 2012; Zhou ve Brown, 2014). The most common developmental theories dwell on social skills and autonomy development in child development. Children continue to get knowledge on environment as long as they are encouraged to have a positive attitude towards environment and environmental issues, thereby figuring out their environments better. In order to enable children to accomplish this, environment education must be provided from early childhood period. Having 
experiences on environment from this period will raise awareness towards environment during this period PheiIce and Griffore, 2003; Wilson, 2009). Parents can enable their children to have positive attitudes and behaviors on environment, by being a role model until their adulthood periods. If not, there may occur disruptive behaviors as to environmental issues (Green, 2015). Only gaining cognitive skills doesn't necessarily mean that individuals will be sensitive to environmental issues. Rather, they must be encouraged to internalize environmental issues (Öztürk, 2013). In this regard, Pooley and O'Connor (2000) noted that the main focus of environmental education programs must be to change environmental behavior through increasing environmental knowledge.

Developed by Bandura, Social Learning Theory (SLT), also called as Learning Theory by Observation, is a learning method based on observing others' behaviours and taking them as a model. In SLT, the behaviours or attitudes of the observers change in either positively or negatively after observation process (Bandura,1977; 1986). The most important pattern of SLT is the model taken as an example. In order for children to learn a behaviour, it must be displayed by others. New congitive skills and behaviours can be gained by observing the model. By observing the behaviors demonstrated by the model, children learn what to do or not, how to motivate, how to use the environment as well as how to use objects. In addition, the high status of the models and the exemplary behaviors of the teachers and the leaders in the schools increase the interaction between the model and the observer (Korkmaz, 2011). There are four mediational processes of learning by observing in SLT (Bandura, 1978):

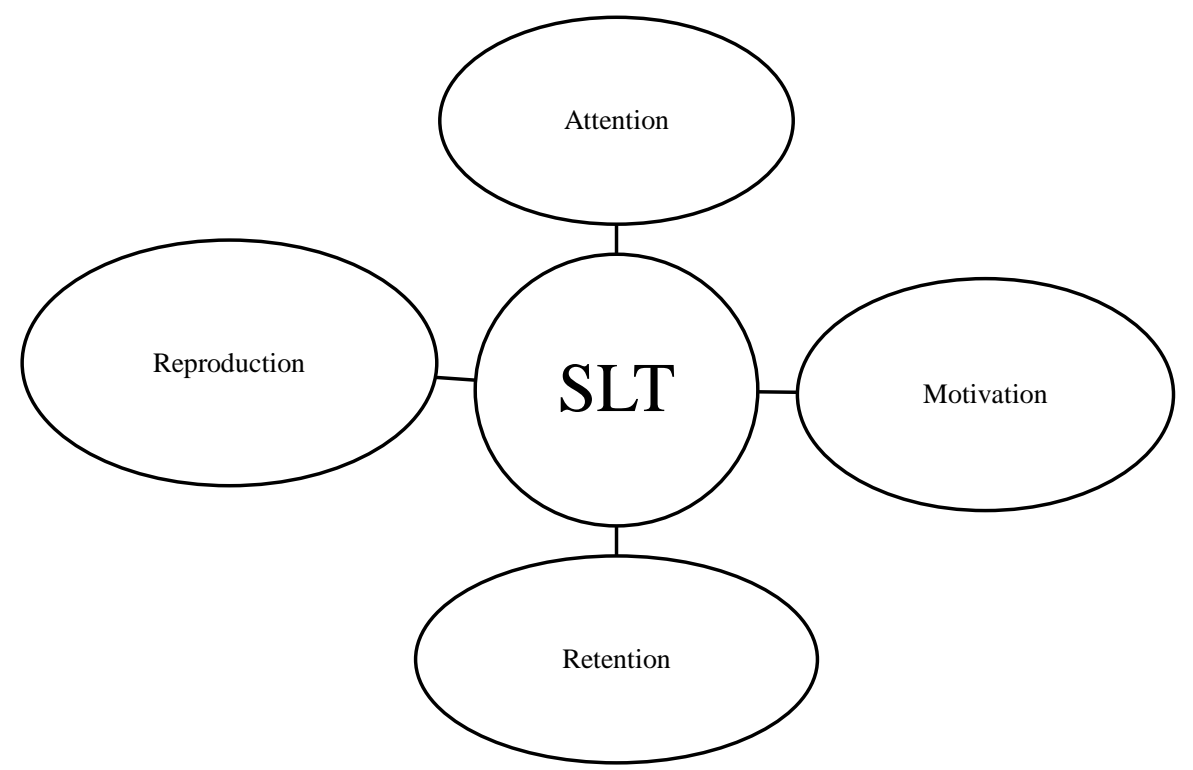

Figure 1. Four Mediational Processes in SLT (Bandura, 1978).

1- Attention: Behaviours are paid attention and are imitated according to the extent to which an individual are exposed to a behaviour demonstrated by influential models, such as mother, father, teacher or a celebrity or models who have similar age and gender.

2-Retention: It is important that a memory of the behaviour learned via observation or imitation is remembered later by the observer.

3-Reproduction: It is also important that a memory of the behaviour must be taken as an example by the observer.

4-Motivation: It is important to have a motivation to perform observed behaviour at a later time voluntarily or by having a reason to do.

In learning by observation, being a role model teaches new behaviours, affects the frequency of learned behaviours and their repetitions, encourages behaviours prohibited before and increases the frequencies of similar behaviours, triggering the feelings (Yüksel, 2014). Environmental factors have an influence of decisions of the individuals, while the events happening in our immediate environment may lead the individual regarding how to behave (Korkmaz, 2011). Environmental education plays an important role in saving and improving the environment in which we live. Environmental education can be defined as developing the conscious of environment in all components in the society, bringing individuals in awareness on environment and positive attitudes and behaviours, taking responsibility as well as taking action in solving of the problems. More conscious individuals can be raised thanks to an effective environmental education in society. It can be said that environmental education is a universal and social concept 
which must be achieved in younger ages. Young generation raised in this perspective is more likely to behave sensitively and consistenly on the issues related to environment (Pehlivan et al., 2009).

Upon closer reading of widespread evidence in literature on enviromental education, it can be seen that not only effectiveness of courses but also activities performed on environmental education don't have expected impact and it can be argued that efforts have been in vain (Sağır, Aslan \& Cansaran, 2008; Şimşekli, 2004; Uzun \& Sağlam, 2005; Ünal \& Dımışık, 1999; Yücel \& Morgil, 1999; Zachariou, Tsami, Chalkias \& Bersimis, 2017). Within this context, an attempt was made to evaluate environmental education in a new perspective in terms of studies and observations on it as well as to reveal its importance by means of taking role model in this study. The purpose of this current study was to evaluate the adult environmental awareness behaviours in terms of SLT according to perceptions of primary and secondary school students. In line with this aim, the sub-research questions framed the study:

1. How do students perceive adults' behavior towards the environment in general terms?

2. Do the ways in which students perceive adults' behavior towards the environment show meaningful differences according to gender?

3. Do the ways in which students perceive adults' behaviors towards the environment show meaningful differences according to class levels?

4. Do the ways in which students perceive adults' behavior towards the environment show meaningful differences according to the levels of school (primary and secondary)?

5. Do the ways in which students perceive adults' behavior towards the environment show meaningful differences according to the educational backgrounds of students' parents?

\section{Method}

This study is a descriptive one that was aimed at determining the theme properties of the research (Can, 2014).

\subsection{Participants}

The participants of this study consisted of students in primary and secondary schools in Amasya city of Turkey. The study group of the study was comprised of 311 students selected randomly. The size of the sample was defined as 311 participants since the standart average must be 245 people if the population has 50.000 individuals in homogeneous groups (Can, 2014). The numbers of the students in primary and secondary schools have been shown in Table 1.

Table 1. Primary and secondary student numbers in Amasya province

\begin{tabular}{lcc}
\hline School Type & Student Numbers & Study Group \\
\hline Primary & 17.700 & 135 \\
Secondary & 18.277 & 176 \\
\hline Total & $\mathbf{3 5 . 9 7 7}$ & $\mathbf{3 1 1}$ \\
\hline
\end{tabular}

2.2 Data Collection Instruments

In this research, "Survey of Adults' Behaviours related to Environment" developed by the researcher was employed as the data collection instrument. In the development of the scale, related literature was investigated and a list of items of the scale was formed. Then, a 20-item scale was prepared by taking the opinions of academicians. In order to test the developed scale, it was applied to a group of 15 students and then piloted with 275 elementary and secondary school students outside the sample group. Factor analysis was conducted as the result of application. Substance factor loads were determined as the result of the analysis. In terms of not compromising the validity of the scopes, 0.20 and 20 items with substance loadings were preserved on the scale and evaluated as a one dimensional scale (Büyüköztürk, 2009; Can, 2014). The Cronbach Alpha reliability coefficient of the scale was 0.80 .

\subsection{Analysis of Data}

SPSS 22 Software was utilised for the analysis of the obtained data. In this context, histogram graph and skewnesskurtosis values were determined to test whether the data conformed to the normal distribution. When the values of the skewness and kurtosis are divided by the standard errors, the value is assumed to be normal distribution (Can, 2014) because it is between -1.96 and +1.96 . Furthermore, whether the differences between group means were meaningful was examined by using the independent $t$ test and the one-way ANOVA test. 


\section{Findings}

This part of the study contains information on the results of the research. Responses to the data collection instrument developed for research were examined separately according to the gender, class levels, school levels (primary and secondary) and parental education levels of the students.

\subsection{Students' Evaluations Related to Adults' Environmental Behaviours}

There are 20 items, including "I observe that adults are sensitive to environmental problems, they throw plastic waste into the recycle bin, turn off unnecessary lights, observe that they participate in environmental campaigns and do not spit in places". The range of scores obtained on the scale varies between 20 and 60 points. When the sum of the evaluation scores from the data obtained from the students is about 20 , the frequency of the adults showing positive environmental behaviors is "Never (1 point)". When it is close to 40 points, the frequency of adults showing positive behaviors about the environment is "Sometimes ( 2 points)". Finally, when 60 points are approached, the frequency of adults showing positive behaviors towards the environment is evaluated as "Always ( 3 points)". Accordingly, students generally assessed adults' environmental behavior as shown in Table 2. As seen in Table 2, students perceive adults as having an average perception of their environment behavior, that is, they show these behaviors as "Sometimes (2 points)".

Table 2. The perception levels of students on adults' environmental behaviours

\begin{tabular}{lcc}
\hline Gender & N & $\bar{x}$ \\
\hline Female & 142 & 43,58 \\
Male & 169 & 40,89 \\
\hline
\end{tabular}

$\begin{array}{lll}\text { Total } & \mathbf{1 3 4} & \mathbf{4 2 , 1 3}\end{array}$

\subsection{Evaluating Students' Perceptions about Adults' Environmental Behaviours in Terms of Gender}

The results of the t-test conducted for determining whether the way the students perceive adults' behaviors show difference according to gender has been given. As seen in Table 3, the mean scores of female and male students regarding the evaluations of the adults' environmental behaviours show differences. According to this, mean scores of female students were 43.58, while male students mean scores were 40.89. As shown in Table 3, a significant difference was found according to the t-test result to determine whether the difference between the average of these two groups was significant $(\mathrm{p}<0.05)$.

Table 3. T-test results on students' perceptions about adults' environmental behaviours in terms of gender

\begin{tabular}{lcrllll}
\hline Gender & $\mathbf{N}$ & $\bar{x}$ & $\mathbf{S}$ & $\mathbf{t}$ & Sd & p \\
\hline Female & 142 & 43,58 & 5,928 & 4,127 & 309 &, 000 \\
Man & 169 & 40,89 & 5,587 & & &
\end{tabular}

$\mathrm{p}>0,05$

\subsection{Evaluating Students' Perceptions Towards Adults' Environmental Behaviours in Terms of Grade Level}

The distributions of students' perceptions towards adults' environmental behaviours in terms of grade level are shown in Table $4.3^{\text {rd }}$ and $4^{\text {th }}$ grades students from primary schools and $5^{\text {th }}, 6^{\text {th }}, 7^{\text {th }}$ and $8^{\text {th }}$ grade level students were included in the study since they were considered as more convenient to respond the questionnaire in terms of maturity. The sample was compromised of 311 pupils.

Table 4. The perception levels of students on adults' environmental behaviours in terms of grade level

\begin{tabular}{lll}
\hline Grade & $\mathbf{N}$ & $\bar{x}$ \\
\hline 3 & 67 & 41,74 \\
4 & 68 & 41,39 \\
5 & 28 & 41,89 \\
6 & 54 & 43,42 \\
7 & 25 & 42,52 \\
8 & 69 & 42,17 \\
\hline Total & $\mathbf{3 1 1}$ & $\mathbf{4 2 , 1 3}$ \\
\hline
\end{tabular}


As shown in Table 4 , the mean scores can be listed as; $3^{\text {rd }}$ grade students $(\bar{x}=41.74), 4^{\text {th }}$ grade students $(\bar{x}=$ 41.39), 5th grade students $(\bar{x}=41.89)$, 6th grade $(\bar{x}=43,42)$, 7th grade $(\bar{x}=42,52)$ and 8th grade $(\bar{x}=42,17)$. According to t-test results, it can be seen that there isn't significant differences among the mean scores of grades $\mathrm{F}$ $(5-305)=0,819, \quad p>0,05$. This result shows that the perceptions of students towards adults' environmental behaviours don't differ in mean scores in terms of grade levels.

One-way ANOVA test was conducted in order to test whether the perceptions of students different grades towards adults' environmental behaviours in terms of grade levels differ significantly and the results are displayed in Table 5.

Table 5. One-way ANOVA test results of students' perceptions towards adults' environmental behaviours in terms of grade levels

\begin{tabular}{llllll}
\hline Sources of Variance & $\begin{array}{c}\text { Sum of Squares } \\
(\mathbf{S S})\end{array}$ & Sd & Mean Square & F & p \\
\hline Between Groups & 142,594 & 5 & 28,51 &, 819 &, 537 \\
Within Groups & 10621,001 & 305 & 34,82 & & \\
\hline Total & $\mathbf{1 0 7 6 3 , 5 9 5}$ & $\mathbf{3 1 0}$ & &
\end{tabular}

3.4 Evaluating Students' Perceptions Towards Adults' Environmental Behaviours In Terms of School Level

T-test results conducted for determining whether students' perceptions towards adults' environmental behaviours in terms of school level (primary and secondary) has been given. As seen in Table 6, although the mean scores of primary students $(\bar{x}=41,57)$ and secondary students $(\bar{x}=42,56)$ show differences in terms of evaluating the adults' environmental behaviours, there isn't any significant difference according to t-test which was conducted to test whether the mean scores of these two groups are significant $(\mathrm{p}<0,05)$.

Table 6. T-test results of students' perceptions towards adults' environmental behaviours in terms of school levels

\begin{tabular}{lcccccc}
\hline $\begin{array}{l}\text { School } \\
\mathbf{N}\end{array}$ & Type & $\bar{x}$ & $\mathbf{S}$ & $\mathbf{t}$ & Sd & $\mathbf{p}$ \\
\hline Primary & 135 & 41,57 & 5,449 & $-1,474$ & 309 &, 141 \\
Secondary & 176 & 42,56 & 6,191 & & \\
\hline
\end{tabular}

$\mathrm{p}>0,05$

3.5 Evaluating Students' Perceptions Towards Adults' Environmental Behaviours in Terms Of Parents' Educational Background

In evaluating students' perceptions towards adults' environmental behaviours in terms of parents' educational background, mothers' educational background was examined initially, then that of fathers was checked. The distribution of mothers' educational background is presented in Table 7. One-way ANOVA test was conducted in order to test whether the perceptions of students different grades towards adults' environmental behaviours in terms of mothers' educational background differ significantly and the results are displayed in Table 8.

Table 7. The perception levels of students on adults' environmental behaviours in terms of mothers' educational background

\begin{tabular}{lll}
\hline Mother Educational Background & $\mathbf{N}$ & $\bar{x}$ \\
\hline Primary & 54 & 41,62 \\
Secondary & 72 & 42,84 \\
High School & 104 & 41,60 \\
University & 81 & 42,50 \\
\hline Total & $\mathbf{3 1 1}$ & $\mathbf{4 2 , 1 3}$
\end{tabular}

As shown in Table 7, the mean scores of the students whose mothers have primary grade degree is $(\bar{x}=41,62)$, secondary is $(\bar{x}=42,84)$, high school is $(\bar{x}=41,60)$ and university is $(\bar{x}=42,50)$. According to t-test results, it can be seen that there isn't significant differences among the mean scores of grades $F(3-307)=0,869, p>0,05$. This result shows that the perceptions of students towards adults' environmental behaviours don't differ in mean scores in terms of mothers' educational background. 
Table 8. One-way ANOVA test results of students' perceptions towards adults' environmental behaviours in terms of mothers' educational background

\begin{tabular}{lllll}
\hline Sources of Variance & $\begin{array}{l}\text { Sum of Squares } \\
\text { (SS) }\end{array}$ & Sd & Mean Square & F \\
\hline Between Groups & 90,599 & 3 & 30,200 & p \\
Within Groups & 10672,995 & 307 & 34,765 & 458 \\
\hline Total & $\mathbf{1 0 7 6 3 , 5 9 5}$ & $\mathbf{3 1 0}$ & \\
\hline In evaluating students' perceptions towards adults' environmental behaviours in terms of parents' educational \\
background, the distribution of fathers' educational background is presented in Table 9. One-way ANOVA test was \\
conducted in order to test whether the perceptions of students different grades towards adults' environmental \\
behaviours in terms of fathers' educational background differ significantly and the results are displayed in Table 9. \\
Table 9. The perception levels of students on adults' environmental behaviours in terms of fathers' educational \\
background \\
\hline Mother Educational Background & $\mathbf{N}$ & $\bar{x}$ \\
\hline Primary & 15 & 39,00 \\
Secondary & 43 & 42,34 \\
High School & 128 & 42,48 \\
University & 125 & 42,07 \\
\hline Total & $\mathbf{3 1 1}$ & $\mathbf{4 2 , 1 3}$ \\
\hline
\end{tabular}

As shown in Table 7, the mean scores of the students whose fathers have primary grade degree is $(\bar{x}=39,00)$, secondary is $(\bar{x}=42,34)$, high school is $(\bar{x}=42,48)$ and university is $(\bar{x}=42,07)$. According to t-test results, it can be seen that there aren't significant differences among the mean scores of grades $F(3-307)=1,598 p>0,05$. This result shows that the perceptions of students towards adults' environmental behaviours don't differ in mean scores in terms of fathers' educational background.

Table 10. One-way ANOVA test results of students' perceptions towards adults' environmental behaviours in terms of fathers' educational background

\begin{tabular}{llllll}
\hline Sources of Variance & $\begin{array}{l}\text { Sum of Squares } \\
\text { (SS) }\end{array}$ & Sd & Mean Square & F & p \\
\hline Between Groups & 165,507 & 3 & 55,16 & 1,598 &, 190 \\
Within Groups & 10598,088 & 307 & 34,52 & & \\
\hline Total & $\mathbf{1 0 7 6 3 , 5 9 5}$ & $\mathbf{3 1 0}$ & & & \\
\hline
\end{tabular}

\section{Discussion and Result}

In this present study, which intends to examine the perceptions of primary and secondary school students towards the behaviours of adults related to the environment, as indicated by the findings, students perceive adults' environmental behaviours as "sometimes" in a positive way. That is to say, positive bevaiours displayed by adults are observed not usually, but sometimes. This perception showed significant differences in favor of girls in terms of gender variable. It was found that there was no significant differences in terms of grade level, school grade (primary and secondary) and parental educational background. Since there hasn't been any research related to the environmental behaviours of adults in the existing literature, citations are directed to similar studies. When compared to other studies, the work of Bayrakçı (2007) tell us that it may be an effective model for the teachers to develop positive attitudes to students in the learning activities and to develop scientific attitudes in case of using visual objects, life models and mass media as social interaction tools in teaching in an application which benefits from SLT in education. In a study focusing on knowledge and awareness levels of students from four different schools in Malaysia and conducted by Said, Yahaya ad Ahmadun (2007), it was found that students learn about the environment largely from sources such as TV and internet which are mass media. In addition, students learn about the environment largely from sources such as TV and internet which are mass media. Moreover, with regard to environmental education and awareness 
raising, it is more effective to study and make observations in the ecological environment, to prepare models for the care of animals and plants, and to make presentations in order to solve problems (Zdrowka \& Atasoy, 2008; Rafferty \& Laird, 2013). This situation can be seen as a compelling evidence that it is easier to take attention of students via attractive tools.

In their studies examining the knowledge and attitudes of students on environment, Sağır, Aslan and Cansaran (2008) found that there weren't any significant differences in terms of grade level and gender of students environmental attitudes, while there was significant difference in terms of grade level on environmental knowledge other than gender. Çimen (2009) also argued that there was significant difference in favor of girls other than grade levels on environmental attitudes in university students. The fact that girls' attitudes towards the environment and perceptions differ significantly from boys can indicate that girls are more involved in environmental activities. This finding concurs well with this present study.

Researches to evaluate studies on environmental education given at different levels show that most of the lessons and activities carried out in schools are inadequate (Çimen, 2008; Sağır, Aslan \& Cansaran, 2008; Said, Yahaya \& Ahmadun, 2007; Şimşekli, 2004; Taycı \& Uysal, 2009; Uzun \& Sağlam 2005; Ünal \& Dımışık 1999; Yücel \& Morgil 1999) in efforts to improve environmental knowledge and awareness and students learn from the mass media about a large part of the environmental information (Holbert, Kwak \& Shah, 2010; Said, Yahaya \& Ahmadun, 2007) and it is essential to adopt new point of view and new studies in environmental education. Students' insufficient awareness on environment, environment morals, nature love and superficiality of ecological culture can be considered among the basic reasons of this. Additionally, courses are provided to children through convential teaching methods, in which teachers are active, whereas students act as a knowledge receiver. This situation, therefore, blocks growing environmentally friendly generations for the future (Tayc1 ve uysal, 2009). This may require to consider socio-cultural factors which have an impact upon individual behaviours put forward by SLT (Bandura, 2001) such as economic conditions, education, family structure, status, self-efficacy perceptions and self-evaluations..

The more people around children are sensitive to environment and display positive behaviors, the more children have interests on environmental issues. In studies surveyed secondary school pupils (Begelholz, 1990; Sivek, 2002), they noted that students gain similar beneficial experiences in environment social clubs. It was suggested that children gain most of their experiences on nature thanks to such activities as games, hikings, fishing and picking up fruits, which are also involved by family members as role models. These findings suggest that behaviors of parents, teachers and others during childhood period are significant for a healthy environment education and will guide for the future steps on environment (Chawla ve Cushing, 2007; Chawla, 2007 ).

Role models may encourage students to develop positive attitudes on environmental education. Studies show that role models play an important role in making students achieve meaningful experiences and develop environmental behaviours. Thanks to educational activities, the models who are observed by children can be changed and children can be directed to more effective models (Stern, Frensley, Powell, ve Ardoin, 2018). From these models, teachers exhibit behaviors such as self-efficacy and feedback which can ease learning. Students tend to believe their teachers' explanations and learn their skills, by observing their actions. Existing literature has documented evidence that children are affected by behaviors rather than suggestions or direct preachings. Similarly, peer models can also support students' learning and motivation. In this regard, observing a peer may yield fruitful results (Shunk, 2012). In the study conducted by Pooley and O'Connor (2000), it was suggested that environmental educators who deal with changing environmental attitudes, emotions and beliefs, instead of knowledge, need to be targeted as sources of information on which to base their environmental programs. Tanner (1980) concluded in the study which dwelled on environmental education that practices in environmental education encompasses taking field trips to more or less natural settings on rare occasions and in large groups, at best and suggested that much more must be done, even if it means a radical departure from traditional policy. When it comes to safety and liability, students can be accompanied by adults who might be retired persons or other volunteers with an interest in children and nature.

\subsection{Implications and Recommendations}

The findings of present study has some implications for environment education and awareness. With regard to make students gain positive attitudes towards the environment, organizing campaigns and activities effectively using reputable, talented, knowledgeable scientists, politicians, educators and artists recognized in the community can positively influence the thoughts of children and adults. They regard adults as role models for themselves, and thanks to this, they can adapt good attitudes and behaviours which they observe in adults. Based on the existing literature which concurs well with this study, it is important to point out that environment education should be started in early childhood period. Several mass media, such as television and internet can be employed in environment education. 
Conducting observations in ecological environment as well as preparing models for animals or plants caring may yield conclusive benefits for having positive attitude on environmental issues. Future experimental studies could inquire into how children can have better education on environment. We have to learn on this important issue.

\section{References}

Amasya MEM. (Amasya Province National Directorate of Education). (2015). Stratejik plan. Retrieved from Amasya meb.gov.tr/dowland/arge/2015-2019SP.pdf

Bandura, A. (1977). Self-Efficacy: Toward A Uniying Theory of Behavioral Change. Psyhological Reviev, 84(2), 191-215. https://doi.org/10.1037/0033-295X.84.2.191

Bandura, A. (1978). Social Learning Theory of Agression. Journal of Communication, 28(3),12-29. https://doi.org/10.1111/j.1460- 2466.1978.tb01621

Bandura, A. (1986). Social Foundations of Thought and Action. A Social Cognitive Theory. Englewood Cliffs. NJ. Prentice Hall.

Bandura, A. (2001). Social Cognitive Theory: An Agentic Perspective. Annual Review Psychology, 52, 1-26. https://doi.org/10.1146/annurev.psych.52.1.1

Bayrakçı, M. (2007). Sosyal Öğrenme Kuramı Ve Eğitimde Uygulanması. Sakarya Üniversitesi Eğitim Fakültesi Dergisi, 14, 198-210.

Büyüköztürk, Ş. (2009). Sosyal Bilimler İçin Veri Analizi El Kitabı. Ankara: Pegem.

Can, A. (2014). SSPS Ile Nicel Veri Analizi. Ankara: Pegem.

Chawla, L. and Cushing, D. B. (2007). Education For Strategic Environmental Behavior. Environmental Education Research, 13(4), 437-452. https://doi.org/10.1080/13504620701581539

Chawla, L. (1999). Life Paths into Effective Environmental Action. The Journal of Environmental Education, 31(1), 15-26. https://doi.org/10.1080/00958969909598628

Çimen, O. (2008). “Çevre Eğitiminde Tatlısu Ekosistemleri Konusundaki Temel Kavramların Üniversite Öğrencileri Tarafından Algılanma Düzeyleri.” Master's thesis, Gazi Üniversitesi Eğitim Bilimleri Enstitüsü. Ankara.

Green, D., Kalvaitis, D. \& Worster, A. (2016) Recontextualizing psychosocial development in young children: a model of environmental identity development. Environmental Education Research, 22(7), 1025-1048. https://doi.org/10.1080/13504622.2015.1072136

Holbert, R. L., Kwak, N. \& Shah, D. V. (2010). Environmental Concern, Patterns Of Television Viewing, And Pro-Environmental Behaviors. Journal of Broadcasting \& Electronic Media, 47(2), 177-196. https://doi.org/10.1207/s15506878jobem4702_2

Korkmaz, İ. (2011). Sosyal Öğrenme Kuramı. In Eğitim psikolojisi, Ed. Yeşilyaprak, B. 246-269). Ankara: Pegem.

Kostowa, Z. \& Atasoy, E. (2008). Methods Of Successful Learning İn Environmental Education. Egitimde Kuram ve Uygulama, 4(1) 49-78. Retrieved from http://eku.comu.edu.tr/index/4/1/ zkostova_eatasoy.pdf

Pehlivan, E., Küçüker, N. Ç., İlksöz, A., Özben, Ş., Güç, A. \& Şen, D. (2009). Konya İlinde Okullarda (İlköğretim Lise ve Üniversite) Çevre Eğitimi Düzeyinin Belirlenmesi. Fen, sosyal ve çevre eğitiminde son gelişmeler sempozyumu bildiriler kitabl. 18-20 November, Giresun.

Phenice, L.A. \& Griffore, R. J. (2003). Young Children and the Natural World. Contemporary Issues in Early Childhood, 4(2). https://doi.org/10.2304/ciec.2003.4.2.6

Pooley, J. A., \& O'Connor, M. (January 01, 2000). Environmental Education and Attitudes: Emotions and Beliefs Are What Is Needed. Environment \& Behavior, 32(5), 711-723. https://doi.org/10.1177/0013916500325007

Rafferty, R. \& Laird, S. G. (2013). Children's Observations of Place-Based Environmental Education. Journal of Sustainability Education, (5). Retrieved from http://www.susted.org/

Sağır, Ş. U., Aslan, O. \& Cansaran, A. (2008). İlköğretim Öğrencilerinin Çevre Bilgisi ve Çevre Tutumlarının Farklı Değişkenler Açısından İncelenmesi. Elementary Education Online, 7(2). Retrieved from http://ilkogretim-online.org.tr

Said S, M., Yahaya, N. \& Ahmadun, F. (2007). Environmental Comprehension and Participation Of Malaysian Secondary School Students. Environmental Education Research, 13(1), 17-31. https://doi.org/10.1080/13504620601122616 
Schunk, D. H. (2012). Learning Theories. Boston: Pearson

Stern, M. J., Frensley, B.T., Powell, R. B. \& Ardoin, N. M. (2018). What Difference Do Role Models Make? Environmental Education Research, 24(6), 818-830. https://doi.org/10.1080/13504622.2017.1313391

Şimşekli, Y. (2004). Çevre Bilincinin Geliştirilmesine Yönelik Çevre Eğitimi Etkinliklerine İlköğretim Okullarının Duyarlılığı. Uludă̆ Üniversitesi Ĕgitim Fakültesi Dergisi,17(1), 83-92.

Öztürk, F. (2013). Uluslararası Bir Çevre Eğitimi Projesinin Fen ve Teknoloji Öğretmen Adaylarının Çevre Bilincine Etkisi. Doctoral thesis, Hacettepe Üniversitesi Eğitim Bilimleri Enstitüsü. Ankara.

Tanner, T. (1980). Significant Life Experiences: A New Research Area in Environmental Education. The Journal of Environmental Education, 11(4), 20-24. https://doi.org/10.1080/00958964.1980.9941386

Tayc1, F. \& Uysal, F. (2009). Çorluda Birinci ve İkinci Kademe İlköğretim Öğrencilerine Çevre Eğitimi Konusunda Uygulanan Anket Çalışması. Fen, sosyal ve çevre eğitiminde son gelişmeler sempozyumu bildiriler kitabı. 18-20 Kasim Giresun.

Uzun, N. \& Sağlam, N. (2007). Ortaöğretimde Çevre Eğitimi ve Öğretmenlerin Çevre Eğitimi Programları Hakkındaki Görüşleri. Eurasian Journal of Educational Research, 26, 176-187.

Ünal, S. \& Dımışk1, E. (1999). Unesco-Unep Himayesinde Çevre Eğitiminin Gelişimi ve Türkiye'de Ortaöğretim Çevre Eğitimi. Hacettepe Üniversitesi Eğitim Fakültesi Dergisi, 16-17, 142 - 154.

Wilson, R. A. (1996). Starting Early: Environmental Education During the Early Childhood Years. ERIC Digest. Retrived from https://files.eric.ed.gov/fulltext/ED402147.pdf

Yücel, A.S. \& Morgil, F. İ. (1999). Çevre Eğitiminin Geliştirilmesi. Balıkesir Üniversitesi Fen Bilimleri Enstitüsü. Dergisi, 1(1), 76-89.

Yüksel, G. (2014). Bir Bilim Olarak Eğitimin Psikolojik Temelleri. In Eğitim Bilimine Giriş, Ed. Özdemir, Ç. 207-231. Ankara: Pegem.

Zachariou, F., Tsami, E., Chalkias, C. \& Bersimis, S. (2017). Teachers' Attitudes Towards The Environment and Environmental Education: An Empirical Study. International Journal of Environmental \& Science Education, 12(7), 1567-1593.

Zhou, M. ve Brown, D. (2014). Educational Learning Theories. Retrived from https://rrscholar. openrepository. $\mathrm{com} / \mathrm{rrscholar} / \mathrm{bitstream} / 10758 / 337833 / 1 /$ EDUC2130+Textbook+Educational+Learning+ Theories.pdf, 